\title{
100 LAT PRAWA KANONICZNEGO na Katolickim Uniwersytecie Lubelskim Jana PaWŁa II
}

\section{Wstęp}

Powstanie w 1918 r. Uniwersytetu Lubelskiego ${ }^{1}$ stanowi jednocześnie początek badań naukowych i dydaktyki w zakresie dyscypliny prawo kanoniczne. Określająca tożsamość Uniwersytetu dewiza Deo et Patriae Bogu i Ojczyźnie, ukierunkowała wysiłek badawczy i dydaktyczny na służbę Kościołowi i ojczyźnie. Celem było kształcenie katolickich elit intelektualnych dla instytucji kościelnych, jak i ubogacanie duchem chrześcijańskim struktur państwa polskiego poprzez obejmowanie różnych funkcji i urzędów przez absolwentów KUL.

Wypadająca w tym roku 100. rocznica powstania KUL i Wydziału Prawa, Prawa Kanonicznego i Administracji skłania do jubileuszowej retrospekcji na historię i dokonania kanonistów oraz ich zasługi dla Kościoła i ojczyzny. Zmieniająca się na przestrzeni lat struktura wydziału wydaje się stanowić pomocny przewodnik dla ukazania zasłużonych naukowców, jak i efektów ich badań.

* Dr hab., prof. Katolickiego Uniwersytetu Lubelskiego Jana Pawła II; e-mail: kburczak@kul.pl.

1 Uniwersytet Lubelski to pierwotna nazwa. W dokumentach kierowanych do Stolicy Apostolskiej używano łacińskiej nazwy Universitas Catholica Lublinensis. Od dnia 2 marca 1928 r., czyli od zatwierdzenia przez ministra Wyznań Religijnych i Oświecenia Publicznego Gustawa Dobruckiego statutu Uniwersytetu, zaczęto używać nazwy Katolicki Uniwersytet Lubelski, zob. K. Burczak, Katedra Historii Powszechnego Prawa Kanonicznego, [w:] A. Dębiński i in. (red.), Księga Jubileuszowa z okazji 90-lecia Wydziatu Prawa, Prawa Kanonicznego i Administracji Katolickiego Uniwersytetu Lubelskiego Jana Pawta II, Lublin 2008, s. 403 , przyp. 1 . 
Nazwa wydziału² zmieniała się wielokrotnie:

- Wydział Prawa Kanonicznego i Nauk Moralnych (1918-1923),

- Wydział Prawa Kanonicznego (1923-1984),

- Wydział Prawa Kanonicznego i Nauk Prawnych (1984-1989),

- Wydział Prawa Kanonicznego i Świeckiego (1989-1999),

- Wydział Prawa, Prawa Kanonicznego i Administracji (od 1999 r.).

\section{Wydział Prawa Kanonicznego i Nauk Moralnych}

Od 3 października 1919 r. na wydziale były dwie sekcje: prawno-społeczna i prawno-historyczna. Od 1923/1924 zlikwidowano podział na sekcje i powstało pięć katedr: I Katedra Tekstu Prawa Kanonicznego, II Katedra Tekstu Prawa Kanonicznego, Katedra Publicznego Prawa Kościelnego, Katedra Prawa Rzymskiego, Katedra Prawa Cywilno-Kościelnego. Następnie liczbę katedr powiększono do siedmiu: I Katedra Tekstu Prawa Kanonicznego, II Katedra Tekstu Prawa Kanonicznego, III Katedra Tekstu Prawa Kanonicznego, Katedra Kościelnego Prawa Polskiego, Katedra Kościelnego Prawa Porównawczego, Katedra Publicznego Prawa Kościelnego oraz Źródeł Prawa Kanonicznego, Katedra Prawa Rzymskiego ${ }^{3}$.

Po ukonstytuowaniu się Senatu Akademickiego w dniu 8 grudnia 1918 r., wybrano dziekanów wydziałów. Pierwszym dziekanem Wydziału Prawa Kanonicznego i Nauk Moralnych został ks. Władysław Żongołłowicz ${ }^{4}$. Nazwa wydziału, jako wydziału kościelnego, została zatwierdzona

2 Zob. A. Dębiński, W.S. Staszewski, M. Wójcik (red.), Dziekani Wydziału Prawa, Prawa Kanonicznego i Administracji Katolickiego Uniwersytetu Lubelskiego Jana Pawła II, Lublin 2008, s. 235-237.

3 Zob. M. Greszata, Katedra Kościelnego Prawa Procesowego, [w:] A. Dębiński i in. (red.), Ksiega Jubileuszowa z okazji 90-lecia Wydziatu..., s. 470.

4 Ksiądz Władysław Żongołłowicz (1870-1944), w 1887 r. wstąpił do Seminarium Duchownego w Kownie; święcenia kapłańskie przyjął w 1891 r.; w latach 1891-1895 studiował teologię w Rzymsko-Katolickiej Akademii Duchownej w Petersburgu uzyskując w 1895 r. tytuł magistra teologii. W 1895-1914 był profesorem w Seminarium w Kownie. Gdy był sekretarzem w kowieńskiej kurii biskupiej i profesorem w seminarium, wyjeżdżał do Włoch, Francji, Niemiec i Belgii, aby kształcić się w zakresie prawa kanonicznego. Od 1915 r. był profesorem prawa kanonicznego w Akademii i tam uzyskał w 1917 r. stopień naukowy doktora prawa kanonicznego, zob. K. Burczak, Katedra Historii Powszechnego 
23 stycznia 1919 r. Ksiądz W. Żongołłowicz organizował wydział i wykładał prawo kanoniczne ${ }^{5}$. W roku akad. 1919/1920 miał wykładać prawo małżeńskie i prawo konkordatowe oraz prowadzić seminarium z prawa małżeńskiego ${ }^{6}$.

Kościelnym prawem karnym, po ks. Władysławie Żongołłowiczu, zajmował się ks. Lucjusz Leccisi. Był zastępcą profesora w latach 1919-1922. W 1923 r. pracował już w Kongregacji Konsystorskiej w Rzymie ${ }^{7}$. Wydział od początku swojego istnienia posiadał uprawnienia do nadawania stopnia naukowego licencjata i doktora.

Na wydziale zatrudniano naukowców z innych ośrodków. Jednym z nich był ks. Józef Florczak ${ }^{8}$, który pracował na wydziale ${ }^{9}$ przez dwa lata w roku akad. 1918/1919 i 1919/1920. W roku akad. 1919/1920 był także dziekanem wydziału. W $1921 \mathrm{r}$. został powołany przez papieża Benedykta XV na urząd audytora Roty Rzymskiej i konsultora Kongregacji Sakramentów. W 1929 r. został z tej funkcji zwolniony i powrócił do Polski. Pracował w duszpasterstwie. W 1942 r. Niemcy wywieźli go do Oświęcimia. W dniu 5 maja 1942 r. został przewieziony do Dachau, gdzie zmarł 20 kwietnia 1943 r., a ciało jego zostało spalone w krematorium

Prawa..., s. 403, przyp. 2; K. Burczak, Bronisław Żongołtowicz (1870-1944), [w:] A. Dębiński, W.S. Staszewski, M. Wójcik (red.), Profesorowie prawa Katolickiego Uniwersytetu Lubelskiego, Lublin 2008, s. 549-558.

5 W tym czasie organizowano również Uniwersytet Wileński i zaproponowano jego kandydaturę na dziekana Wydziału Teologicznego. W dniu 28 sierpnia 1919 r. Naczelnik Państwa Marszałek Józef Piłsudski podpisał jego nominację na dziekana Wydziału Teologicznego i ks. W. Żongołłowicz musiał opuścić Uniwersytet Lubelski i udać się do Wilna, zob. K. Burczak, Katedra Historii Powszechnego Prawa..., s. 403-404, przyp. 2.

6 Wykładów tych nie podjął, gdyż w lecie 1919 r. biskup Jerzy Matulewicz i duchowieństwo diecezji chcieli, aby on jako Litwin, a nie ks. Kazimierz Zimmermann z Uniwersytetu Jagiellońskiego organizował Wydział Teologiczny na Uniwersytecie Wileńskim, zob. K. Burczak, Bronistaw Żongołtowicz..., s. 551.

7 Zob. A.G. Miziński, Katedra Kościelnego Prawa Karnego, [w:] A. Dębiński i in. (red.), Księga Jubileuszowa z okazji 90-lecia Wydziału..., s. 440.

8 Ksiądz Józef Florczak (1887-1943), święcenia kapłańskie przyjął w 1910 r.; w latach 1913-1915 odbył studia w Rzymie w Collegium Pontificium Internationale Angelicum, gdzie w 1919 r. uzyskał stopień naukowy doktora teologii, zob. K. Orzeszyna, Józef Florczak (18871943), [w:] A. Dębiński, W.S. Staszewski, M. Wójcik (red.), Profesorowie prawa..., s. 135-136.

9 Przedmiotem wykładów ks. J. Florczaka była historia prawa kanonicznego oraz normy ogólne, a także teologia, natomiast głównym obszarem badań, instytucja celibatu duchowieństwa w Polsce, zob. K. Orzeszyna, Józef Florczak..., s. 137. 
obozu $^{10}$. Dwaj pierwsi dziekani, po krótkim okresie pracy na wydziale zostali powołani na ważne stanowiska uniwersyteckie i sądownictwa kościelnego. W przyszłości jednak ich losy biegły bardzo różnymi drogami.

W dniu 3 października 1920 r. decyzją Rady Wydziału zostały utworzone dwie sekcje: prawno-społeczna i prawno-historyczna, a następnie prawno-moralna ${ }^{11}$. Rektor KUL ks. Idzi Radziszewski podejmował starania o pozyskanie do pracy na Uniwersytecie wykładowców dla różnych dyscyplin. Efektem jego starań było przybycie z Belgii o. Gommara Michielsa $^{12}$, kapucyna. Po uzyskaniu w dniu 28 czerwca 1920 r. stopnia naukowego doktora prawa kanonicznego, już w dniu 11 lipca 1920 r. przybył on do Lublina i rozpoczął pracę naukową i dydaktyczną, a także wyróżnił się w pracy organizacyjnej. Jedną z pierwszych jego inicjatyw było założenie biblioteki wydziałowej. Wprowadził obowiązek publikowania rozpraw doktorskich przed egzaminem doktorskim. Pod jego kierunkiem powstało osiem prac doktorskich. Z jego inicjatywy wprowadzono trzyletnie studia licencjackie ${ }^{13}$. Urząd dziekana pełnił w latach 1924-1928 i 1931-1935; w roku akad. 1928/1929 był prodziekanem. Po utworzeniu na Uniwersytecie Wydziału Teologicznego, zmieniono nazwę wydziału na Wydział Prawa Kanonicznego.

10 Zob. tamże, s. 136.

11 Zob. A. Dębiński i in. (red.), Informator - Wydział Prawa, Prawa Kanonicznego i Administracji KUL, Lublin 2005, s. 15.

12 Ojciec Józef Gommar Michiels (1890-1965), święcenia kapłańskie przyjął w 1914 r.; w tym roku został skierowany na studia z prawa kanonicznego do Rzymu na Uniwersytet Gregoriański. Stopień naukowy doktora prawa kanonicznego uzyskał w dniu 28 czerwca 1929 r. Na wydziale pracował w latach 1920-1935. Przedmiotem jego wykładów w języku łacińskim były: normy generalne, przestępstwa i kary, prawo kanoniczne, prawo osobowe, prawo naturalne, metodologia prawnicza. Jego badania naukowe obejmowały szeroko pojęte prawo kanoniczne, tak że zaliczany jest do „klasyków nauki prawa kanonicznego”, zob. J. Krukowski, Józef Gommar Michiels (1890-1965), [w:] A. Dębiński, W.S. Staszewski, M. Wójcik (red.), Profesorowie prawa..., s. 299-302.

13 Program studiów był tak doskonały, że wzorowano się na nim przygotowując konstytucję apostolską papieża Piusa XI z 1931 r. Deus scientiarum Dominus, na podstawie której należało zreformować studia nauk kościelnych na uniwersytetach. Na mocy tej konstytucji, w szczegółach w Ordinationes wydanych do niej, nakazano w ramach studiów kanonistycznych prowadzić wykład Historia Powszechnego Prawa Kanonicznego. 


\section{Wydział Prawa Kanonicznego}

Ojciec G. Michiels współpracował przy reorganizacji studiów, zmierzającej do przyjęcia wypracowanego przez niego modelu ułożenia przedmiotów w cyklu czterech lat, który Rada Wydziału przyjęła na posiedzeniu w dniu 11 czerwca 1923 r. Obok o. G. Michielsa pozyskano do pracy na wydziale ks. Jana Wiślickiego ${ }^{14}$, który w 1921 r. rozpoczął pracę na Wydziale Prawa i Nauk Społeczno-Ekonomicznych, a od 1922 r. pracował na Wydziale Prawa Kanonicznego i Nauk Moralnych, prowadząc wykłady z historii źródeł i literatury prawa kanonicznego, kościelnego prawa publicznego i innych działów prawa kanonicznego. W związku z brakiem specjalistów, wielu wykładowców prowadziło zajęcia dydaktyczne z różnych działów prawa kanonicznego. Badania naukowe prowadził głównie w obszarze kościelnego prawa publicznego, instytucji zwyczaju w prawie kanonicznym, konkordatów czy prawa małżeńskiego. Pionierskie były badania nad uprawnieniami osób świeckich w Kościele. Był promotorem rozprawy doktorskiej późniejszego Prymasa Polski kardynała Stefana Wyszyńskiego $^{15}$. Na wydziale pracował do 11 listopada 1939 r., kiedy został wraz z innymi profesorami KUL uwięziony przez Niemców na Zamku Lubelskim.

Wykładowcą prawa kanonicznego na wydziale był również ks. Józef Pruszkowski ${ }^{16}$. W roku akad. 1922/1923 prowadził wykłady z prawa kanonicznego, a w następnym roku został już zwolniony ze względu na swój wiek, gdyż wówczas miał 85 lat. Był najstarszym wykładowcą KUL w okresie międzywojennym. Był też historykiem, który zasłużył się udokumentowaniem prześladowań unitów ${ }^{17}$. Polska Akademia Umiejętności,

14 Ksiądz Jan Wiślicki (1879-1944), święcenia kapłańskie przyjął w 1904 r.; studiował prawo kanoniczne na Uniwersytecie Gregoriańskim, gdzie w 1906 r. uzyskał stopień naukowy doktora prawa kanonicznego. Habilitację uzyskał w 1926 r. na Wydziale Teologicznym Uniwersytetu Warszawskiego, zob. M. Sitarz, Jan Wiślicki (1879-1944), [w:] A. Dębiński, W.S. Staszewski, M. Wójcik (red.), Profesorowie prawa..., s. 509-511.

15 Zob. tamże, s. 511.

16 Ksiądz Józef Pruszkowski (1837-1925), święcenia kapłańskie przyjął w 1860 r.; od 1862 r. był wykładowcą w Zakładzie Biblistyki Nowego Testamentu w Seminarium Duchownym w Janowie Podlaskim. Po likwidacji w 1867 r. przez władze carskie Seminarium Duchownego, pracował w duszpasterstwie. W latach 1907-1919 był profesorem prawa kanonicznego w Seminarium Duchownym w Lublinie, zob. M. Ordon, Józef Pruszkowski (18371925), [w:] A. Dębiński, W.S. Staszewski, M. Wójcik (red.), Profesorowie prawa..., s. 387-389.

17 Pod pseudonimem „P.J.K. Podlasiak” wydał dwutomową pracę, Martyrologium czyli męczeństwo Unii na Podlasiu, cz. 1, Kraków 1905, cz. 2, Lublin 1917. 
doceniając wartość jego dorobku naukowego, przyjęła go w 1920 r. do grona swoich członków.

Od 1922 r. zajęcia zlecone z prawa rzymskiego prowadził ks. Henryk Insadowski ${ }^{18}$. Od 1924 r. został zatrudniony jako zastępca profesora na Wydziale Prawa i Nauk Społeczno-Ekonomicznych, ale wykłady z prawa rzymskiego prowadził na obu wydziałach jurydycznych. W latach 19241939 był dyrektorem Biblioteki Uniwersyteckiej. W latach 1929-1933 był delegatem Wydziału Prawa Kanonicznego do Senatu Akademickiego. Urząd prodziekana pełnił w latach 1935-1937, a od 1937 r. do aresztowania przez Niemców w dniu 9 listopada 1939 r., gdy został przez okupantów niemieckich osadzony w Zamku Lubelskim - urząd dziekana. Prawa rzymskiego uczył także w czasie wojny w warunkach konspiracyjnych na Wydziale Teologicznym Ziem Zachodnich w Warszawie. Urząd dziekana pełnił również po wojnie, od reaktywacji Wydziału Prawa Kanonicznego w dniu 7 marca 1945 r. do swojej śmierci - 14 marca 1946 r. Głównym obszarem prac badawczych było prawo rzymskie i prawo kanoniczne. W ramach tych obszarów podejmował analizy badawcze dotyczące wpływu chrześcijaństwa na prawo rzymskie oraz wpływu prawa rzymskiego na prawo kanoniczne. Prowadził zajęcia z prawa Kościoła prawosławnego i prawa katolickich Kościołów wschodnich. W okresie międzywojennym Wydział Prawa Kanonicznego na KUL był jedynym samodzielnym wydziałem tej dyscypliny w Polsce. Na uniwersytetach w Krakowie, Warszawie, Wilnie i Lwowie prawo kanoniczne było nauczane w ramach wydziałów teologicznych ${ }^{19}$.

Na początku kształtowania się wydziału zabiegano o pozyskanie pracowników naukowych z różnych ośrodków. Jednym z nich był wykładowca prawa kanonicznego z teologicznego studium jezuitów z Krakowa, ks. Jan Roth ${ }^{20}$. Pracę w Lublinie rozpoczął w 1924 r. Prowadził zajęcia

18 Ksiądz Henryk Insadowski (1888-1946), święcenia kapłańskie przyjął w 1916 r., studiował prawo kanoniczne na Uniwersytecie Gregoriańskim w Rzymie, gdzie uzyskał stopień naukowy doktora prawa kanonicznego w 1918 r., zob. A. Dębiński, Henryk Insadowski (1888-1946), [w:] A. Dębiński, W.S. Staszewski, M. Wójcik (red.), Profesorowie prawa..., s. 197-199.

19 Tamże, s. 202-203; A. Dębiński i in. (red.), Informator..., s. 15.

20 Ksiądz Jan Roth (1870-1944), święcenia prezbiteratu przyjął w 1900 r.; po krótkim okresie dalszego kształcenia na Uniwersytecie Jagiellońskim został skierowany na studia z prawa kanonicznego na Uniwersytecie Gregoriańskim w Rzymie. Po uzyskaniu doktoratu i habilitacji powrócił do Polski i wykładał prawo kanoniczne w teologicznym 
dydaktyczne z prawa zakonnego, ale też z prawa procesowego, prawa karnego, sakramentów i kultu Bożego oraz wykłady z filozofii prawa. Głównym obszarem badawczym było prawo zakonne, a szczególnie relacje pomiędzy zakonami i biskupami. Był promotorem rozpraw doktorskich, w tym pierwszej z prawa zakonnego w 1929/1930. Wypromował 18 doktorów. Uczestniczył w działalności organizacyjnej wydziału. Funkcje prodziekana pełnił w latach 1925-1928, 1934/1935, 1937/1938, a dziekana - w latach 1928-1931 i 1935-1937. Jako profesor KUL został przez Niemców aresztowany 2 lutego 1940 r., a po uwolnieniu w maju 1940 r. przeniósł się do Warszawy, gdzie nadal prowadził tajne nauczanie. Po upadku powstania warszawskiego w ciężkim stanie zdrowia znalazł się w obozie w Pruszkowie. Zmarł 21 października 1944 r. w Walendowie koło Nadarzyna. Profesorowie Wydziału Prawa Kanonicznego KUL dzielili bolesne losy z całym narodem. Służyli Bogu i ojczyźnie swoim wykształceniem i dla niej poświęcali swoje życie.

Po II wojnie światowej Wydział Prawa Kanonicznego wznowił swoją działalność. Od początku istnienia kształcił przede wszystkim kapłanów. Spośród nich w przyszłości zaczęli rekrutować się pracownicy naukowi, którzy zasilali kadry naukowe i dydaktyczne wydziału. Jednym z nich był ks. Piotr Kałwa ${ }^{21}$, który rozpoczął studia już w 1918 r. Licencjat uzyskał w 1923 r. Po uzyskaniu na Uniwersytecie Jana Kazimierza we Lwowie stopnia naukowego doktora w 1926 r., objął stanowisko zastępcy profesora prawa kościelnego na Wydziale Prawa Kanonicznego KUL. Zakres prowadzonych zajęć był bardzo szeroki i obejmował prawo polskie, kościelne prawo polskie, historię źródeł prawa kanonicznego w Polsce, administrację stosunków wyznaniowych i szkolnych, prawo polskie na Ziemiach Zachodnich, prawo rzymskie, filozofię prawa dla studentów prawa kanonicznego. Stanowi to świadectwo braku odpowiednich specjalistów w danej specjalności prawa kanonicznego i świeckiego w tamtym czasie. Wraz z innymi profesorami KUL został uwięziony przez Niemców 11 listopada

studium jezuitów w Krakowie. W 1924 r. przybył do Lublina, zob. A. Skorupa, Jan Roth (1870-1944), [w:] A. Dębiński, W.S. Staszewski, M. Wójcik (red.), Profesorowie prawa..., s. $443-445$.

21 Ksiądz Piotr Kałwa (1893-1974), święcenia kapłańskie przyjął w 1916 r.; stopień naukowy doktora uzyskał w 1926 r. na Uniwersytecie Jana Kazimierza we Lwowie. Pracę na Wydziale Prawa Kanonicznego rozpoczął w drugim trymestrze roku akad. 1926/1927, zob. M. Stasiak, Piotr Katwa (1893-1974), [w:] A. Dębiński, W.S. Staszewski, M. Wójcik (red.), Profesorowie prawa..., s. 217-218. 
1939 r. na Zamku Lubelskim. W czerwcu 1940 r. wyjechał do Kielc. Po wojnie powrócił na KUL i kontynuował pracę naukową.

Po zatwierdzeniu jego awansu na profesora zwyczajnego dnia 1 kwietnia 1946 r., został kierownikiem Katedry Prawa Kościelnego na Wydziale Prawa i Nauk Społeczno-Ekonomicznych. Funkcję te pełnił do zamknięcia tego wydziału przez władze komunistyczne w 1951/1952 r. Pod jego kierunkiem powstało 16 rozpraw doktorskich i 34 prace magisterskie. Spośród jego studentów sześciu zostało kierownikami katedr na Uniwersytecie. Badania naukowe obejmowały zagadnienia kolędy polskiej jako daniny kościelnej (to jego główne dzieło), adopcja cywilna, małżeństwa mieszane, relacje Kościoła katolickiego z Cerkwią Ruską, ustawodawstwo synodalne. $\mathrm{W}$ jego dorobku jest ponad 40 prac.

Angażował się w instytucjonalny wymiar funkcjonowania Uniwersytetu i samego wydziału. Był delegatem Wydziału Prawa Kanonicznego do Senatu Akademickiego w latach 1933/1934 i 1938/1939. W 1938/1939 został wybrany na dziekana wydziału. Funkcję tę sprawował również w latach 1946/1947 oraz 1949/1950. W latach 1930-1938 był dyrektorem Konwiktu Księży Studentów. W dniu 30 maja 1949 r. został mianowany przez papieża Piusa XII biskupem lubelskim. Z uwagi na nowe obowiązki zredukowano jego pensum dydaktyczne. Gdy przeszedł na emeryturę, przez cztery lata prowadził nadal wykłady do końca roku akad. 1964/1965 22 Jako biskup lubelski był Wielkim Kanclerzem KUL i jako członek Komisji Episkopatu Polski ds. Katolickiego Uniwersytetu Lubelskiego zabiegał o realizację jego potrzeb.

Ksiądz Piotr Kałwa, jako wykształcony na KUL kanonista, stanowił wówczas wyjątek. Władze Uniwersytetu starały się pozyskać specjalistów z prawa kanonicznego z różnych ośrodków naukowych.

W latach 1933-1936 studia na Wydziale Prawa Kanonicznego odbył ks. Teodor Bensch ${ }^{23}$. Po uzyskaniu stopnia naukowego doktora prawa kanonicznego wyjechał na studia administracyjno-sądowe w Rocie Rzymskiej i Kongregacji Soboru. W latach 1937-1939 pełnił funkcję profesora Katedry Tekstu Prawa Kanonicznego. Prowadził wykłady o osobach

22 Zob. tamże, s. 220-223.

${ }^{23}$ Ksiądz Teodor Bensch (1903-1958), święcenia kapłańskie przyjął w 1932 r. Stopień naukowy doktora prawa kanonicznego uzyskał w 1936 r. W latach 1951-1954 był biskupem nominatem dla Gorzowa. W 1954 r. przyjął święcenia biskupie. W latach 1956-1958 był biskupem diecezji gorzowskiej, zob. S. Dubiel, Teodor Bensch (1903-1958), [w:] A. Dębiński, W.S. Staszewski, M. Wójcik (red.), Profesorowie prawa..., s. 17-21. 
w prawie, o miejscach i czasach świętych, o kulcie Bożym o Urzędzie Nauczycielskim Kościoła, o dobrach doczesnych, prawo procesowe. Jego badania naukowe dotyczyły prawa małżeńskiego ${ }^{24}$.

W 1935 r. doktorat z prawa kanonicznego obronił ks. Marian Myrcha. Po uzyskaniu stopnia naukowego doktora habilitowanego w 1947 r. został zatrudniony w III Katedrze Tekstu Prawa Kanonicznego jako zastępca profesora. Wykładał do 1952 r., kiedy otrzymał urlop zdrowotny. W latach 1958-1960 prowadził na Wydziale Prawa Kanonicznego wykłady zlecone ${ }^{25}$.

Wśród pracowników Uniwersytetu znalazł się także ks. Aleksy Petra$\mathrm{ni}^{26}$. Pracę na Wydziale Prawa Kanonicznego rozpoczął 1 listopada 1945 r. na stanowisku zastępcy profesora, natomiast od 15 grudnia 1945 r. - profesora nadzwyczajnego w Katedrze Tekstu Prawa Kanonicznego. Wykładał normy generalne i prawo sakramentów świętych, prawo procesowe (proces zwyczajny i procesy specjalne), prawo zakonne, metodologie prawa kanonicznego. Wypromował 43 doktorów, których prace dotyczyły najczęściej prawa zakonnego, procesowego i kanonizacyjnego. Prodziekanem wydziału był w roku akad. 1949/1950. Główne pola badawcze to historia i dogmatyka prawa kanonicznego. Duże znaczenie mają jego opracowania dotyczące nauki i nauczania prawa kanonicznego w Polsce. Na wydziale pracował 26 lat. Na emeryturę przeszedł w 1971 r. Zmarł w Lublinie w 1977 r.

Losy powojenne Polaków na wschodzie dzielili również kapłani. Jednym z nich był ks. Jan Nowicki ${ }^{27}$. Na Wydziale Prawa Kanonicznego KUL

24 Zob. tamże, s. 19.

25 Zob. A.G. Miziński, Katedra Kościelnego Prawa..., s. 442.

26 Ksiądz Aleksy Petrani (1900-1977), święcenia kapłańskie przyjął w 1923 r.; stopień naukowy doktora teologii uzyskał w 1926 r. w Insbrucku. Prawo kanoniczne studiował w Paryżu i w Papieskim Instytucie Prawa Kanonicznego i Rzymskiego św. Apolinarego w Rzymie, gdzie w 1930 r. uzyskał stopień naukowy doktora prawa kanonicznego. W 1945 r. uzyskał stopień naukowy doktora habilitowanego na Wydziale Teologicznym Uniwersytetu Warszawskiego, zob. W. Bar, Aleksy Petrani (1900-1977), [w:] A. Dębiński, W.S. Staszewski, M. Wójcik (red.), Profesorowie prawa..., s. 373-378.

27 Ksiądz Jan Nowicki (1894-1973), święcenia kapłańskie przyjął w 1919 r. Jako kapłan diecezji lwowskiej w październiku 1924 r. rozpoczął studia z prawa kanonicznego na Uniwersytecie Gregoriańskim. Tam uzyskał stopień naukowy doktora prawa kanonicznego i w 1927 r. powrócił do Polski. Prawo kanoniczne wykładał na Uniwersytecie Jana Kazimierza we Lwowie i w Seminarium Duchownym. Po wojnie Seminarium przeniesiono do Kalwarii Zebrzydowskiej, gdzie wykładał prawo kanoniczne, zob. G. Wojciechowski, Jan Nowicki (1894-1973), [w:] A. Dębiński, W.S. Staszewski, M. Wójcik (red.), Profesorowie prawa..., s. 309-313. 
został zatrudniony w 1950 r. jako profesor nadzwyczajny w Katedrze Historii Źródeł Prawa Kanonicznego i Publicznego Prawa Kościelnego. W 1952 r. musiał przerwać pracę na KUL, gdyż władze państwowe nie zatwierdziły jego stanowiska na wydziale, jednak w 1955 r. został ponownie zatrudniony w charakterze kontraktowego profesora nadzwyczajnego, który to tytuł został mu przyznany przez władze państwowe w 1957 r. Od 1958 r. był kierownikiem Zakładu Prawa Kanonicznego i kierownikiem Katedry Tekstu Prawa Kanonicznego. Wykładał prawo o sakramentach, filozofię prawa, kościelne prawo publiczne i metodologię. W pracy badawczej podejmował różne zagadnienia, takie jak: rezygnacja proboszczów, postulacja, kompetencje spowiedników zakonnych. Efekty badań podejmowanych w tych obszarach zamieszczał w publikacjach naukowych. Od 1957 r. do 1961 r. pełnił urząd dziekana Wydziału Prawa Kanonicznego. Gdy w 1964 r. został mianowany wikariuszem kapitulnym archidiecezji z siedzibą w Lubaczowie, w 1965 r. przeszedł na emeryturę i zakończył pracę na KUL. W 1968 r. został biskupem. Zmarł w 1973 r. w Lubaczowie ${ }^{28}$.

Wydział pozyskiwał pracowników naukowych z innych ośrodków, ale też kształcił duchownych, którzy podejmowali, obok innych zadań w diecezji, także pracę naukową. Jednym z nich był ks. Paweł Pałka ${ }^{29}$. W 1937 r. rozpoczął pracę na KUL na stanowisku starszego asystenta; w 1946 r. był zastępcą profesora; w 1956 r. objął stanowisko docenta, a w 1971 r. otrzymał tytuł naukowy profesora nadzwyczajnego. Wykładał prawo Kościołów wschodnich, prawo o sakramentach, o miejscach i czasach świętych, ustawodawstwo partykularne Kościoła greckokatolickiego w Polsce. Badania naukowe prowadził głównie w dwu obszarach: historia instytucji prawnych Kościoła katolickiego w Polsce i prawo Kościołów wschodnich. Był promotorem siedmiu rozpraw doktorskich. W latach 1950-1957 był dziekanem, a w latach 1957-1972 prodziekanem wydziału.

Wśród naukowców, którzy kształcili się na Wydziale Prawa Kanonicznego KUL i zostali jego pracownikami był ks. Józef Rybczyk ${ }^{30}$. Pracę na Wy-

28 Zob. tamże, s. 310.

29 Ksiądz Paweł Pałka (1904-1992), święcenia kapłańskie przyjął w 1929 r.; od 1932 r. studiował prawo kanoniczne na KUL; w 1936 r. uzyskał stopień naukowy doktora prawa kanonicznego. Przez wiele lat był rektorem Wyższego Seminarium Duchownego w Lublinie, zob. L. Adamowicz, Pawet Patka (1904-1992), [w:] A. Dębiński, W.S. Staszewski, M. Wójcik (red.), Profesorowie prawa..., s. 335-339.

30 Ksiądz Józef Rybczyk (1912-1983), święcenia kapłańskie przyjął w 1937 r. Kształcąc się w zakresie prawa kanonicznego uzyskał stopień naukowy licencjata prawa 
dziale rozpoczął od roku akad. 1949/1950. W 1950 r. został zastępcą profesora III Katedry Tekstu Prawa Kanonicznego. Jako profesor KUL został aresztowany przez Urząd Bezpieczeństwa w dniu 18 lutego 1952 r., a zwolniony 2 lutego 1955 r. Po uzyskaniu w 1955 r. stopnia naukowego doktora habilitowanego, w 1957 r. został kierownikiem III Katedry Tekstu Prawa Kanonicznego. W latach 1965-1972 pełnił też obowiązki kierownika Katedry Publicznego Prawa Kościelnego i Źródeł Prawa Kanonicznego. Jako profesor KUL został w 1967 r. powołany na konsultora Papieskiej Komisji ds. Rewizji Kodeksu Prawa Kanonicznego. Prowadził również zajęcia na Wydziale Teologii, na papieskim Wydziale Teologicznym we Wrocławiu oraz pisał ekspertyzy i opinie dla Konferencji Episkopatu Polski. Na Wydziale Prawa Kanonicznego KUL prowadził wykłady z prawa małżeńskiego, prawa o beneficjach i majątku kościelnym, miejsca i czasy święte, dobra doczesne Kościoła. Był ponadto promotorem wielu rozpraw doktorskich.

Główne pola badawczej pracy naukowej to prawo małżeńskie, w tym przeszkody małżeńskie oraz legitymacja potomstwa oraz prawo osobowe, a także prawo o sakramentach, uprawnienia i obowiązki proboszcza, dziekana. Zajmował się również zagadnieniami ekumenicznymi. Pełnił wiele funkcji administracyjnych. Był dziekanem w latach 1962-1974 i 1977-1978; prodziekanem - w latach 1974-1977 i 1980-1983 oraz prorektorem KUL w latach 1956-1959. Na Katolickim Uniwersytecie Lubelskim pracował 33 lata. Zmarł dnia 29 maja 1983 r. w Lublinie ${ }^{31}$.

W okresie powojennym, w 1945 r. studia z prawa kanonicznego rozpoczął ks. Walenty Wójcik ${ }^{32}$. Również on w przyszłości podjął pracę nauko-

kanonicznego, ale w 1939 r. dalsze studia przerwał wybuch II wojny światowej. W dniu 21 listopada 1939 r. wraz z grupą profesorów i studentów został osadzony przez Niemców na Zamku Lubelskim. Po interwencji ambasadora Stanów Zjednoczonych w 1940 r. - uwolniony. Interwencja ambasadora była powodowana faktem, że urodził się on w Holyoke Mass, w Stanach Zjednoczonych. W 1944 r. w Kielcach uczestniczył w tajnym studiowaniu prawa kanonicznego, które zorganizował tam ks. Piotr Kałwa; pod jego też kierownictwem przygotowywał pracę doktorską. W 1945 r. uzyskał stopień naukowy doktora prawa kanonicznego. W roku akad. 1946/47 odbył studium rotalne w Rocie Rzymskiej i studium administracyjne przy Kongregacji Soboru, zob. S. Jóźwiak, Józef Rybczyk (19121983), [w:] A. Dębiński, W.S. Staszewski, M. Wójcik (red.), Profesorowie prawa..., s. 449-450.

31 Zob. tamże, s. 452-454.

32 Ksiądz Walenty Wójcik (1914-1990), święcenia kapłańskie przyjął w 1939 r. Studia z prawa kanonicznego na KUL rozpoczął w 1945 r.; w 1948 r. uzyskał stopień naukowy doktora prawa kanonicznego. Prawo kanoniczne wykładał w Wyższym Seminarium Duchownym w Sandomierzu od 1948 r. W 1960 r. został biskupem pomocniczym 
wo-dydaktyczną na Wydziale Prawa Kanonicznego. Od 1959 r. prowadził zajęcia zlecone $\mathrm{z}$ historii źródeł i literatury prawa kanonicznego, a także z filozofii prawa. W 1965 r. został starszym wykładowcą, prowadząc od 1966 r. wykłady z historii prawa kościelnego w Polsce. W 1970 r. został docentem i kierownikiem Katedry Historii Źródeł Kościelnego Prawa Polskiego. Wypromował trzech doktorów.

Badania naukowe prowadził głównie w dwu obszarach: historii powszechnego prawa kanonicznego oraz historii ustawodawstwa i instytucji kościelnych w Polsce. Wiele prac poświęcił historii polskiego prawa synodalnego, organizacji oficjalatów okręgowych, instytucjom Diecezji Sandomierskiej, organizacji i prawom kapituł katedralnych i kolegiackich. Jako uczestnik Soboru Watykańskiego II pisał liczne sprawozdania z jego obrad. Był konsultantem Papieskiej Komisji ds. Rewizji Kodeksu Prawa Kanonicznego i w swoich publikacjach prezentował przebieg prac Komisji nad nową kodyfikacją. Opublikował wiele prac o papiestwie, konferencjach episkopatów, biskupstwie, synodach biskupów, radach duszpasterskich i kapłańskich. Pracę na Katolickim Uniwersytecie Lubelskim zakończył w 1984 r., kiedy przeszedł na emeryturę. Zmarł w Sandomierzu 22 listopada $1990 \mathrm{r}$. i został pochowany w podziemiach sandomierskiej katedry ${ }^{33}$.

Wśród profesorów wydziału wykształconych na KUL był również ks. Jerzy Grzywacz ${ }^{34}$. Pracę na KUL rozpoczął w 1953 r., gdzie wykładał prawo kanoniczne w Instytucie Wyższej Kultury Religijnej KUL. Zajęcia zlecone z prawa kanonicznego prowadził na Wydziale Teologii KUL od 1958 r. Od 1962 r. był adiunktem Międzywydziałowego Zakładu Ustroju i Prawa PRL.

Od roku akad. 1965/1966 prowadził wykład na temat kultu Bożego i Nauczycielskiego Urzędu Kościoła na Wydziale Prawa Kanonicznego. W roku akad. 1966/1967 został adiunktem I Katedry Tekstu Prawa Kanonicznego na Wydziale Prawa Kanonicznego. Prowadził też wykład

sandomierskim. Stopień naukowy doktora habilitowanego uzyskał w 1961 r., zob. S. Tymosz, Walenty Wójcik (1914-1990), [w:] A. Dębiński, W.S. Staszewski, M. Wójcik (red.), Profesorowie prawa..., s. 513-523.

33 Zob. tamże, s. 515-519.

34 Ksiądz Jerzy Grzywacz (1923-1995), święcenia kapłańskie przyjął w 1948 r. Studiował na Wydziale prawo kanoniczne w latach 1950-1952, gdzie uzyskał stopień naukowy licencjata prawa kanonicznego, w 1953 r. - doktora prawa kanonicznego, a w 1969 r. - doktora habilitowanego (zatwierdzony przez właściwe ministerstwo w 1970 r.), zob. M. Greszata, Jerzy Grzywacz (1923-1995), [w:] A. Dębiński, W.S. Staszewski, M. Wójcik (red.), Profesorowie prawa..., s. 149-156. 
$\mathrm{z}$ administracji wyznaniowej i prawa rzymskiego. Po uzyskaniu w $1970 \mathrm{r}$. stopnia naukowego doktora habilitowanego został zatrudniony na stanowisku docenta i jednocześnie został kierownikiem II Katedry Tekstu Prawa Kanonicznego. Tytuł naukowy profesora nadzwyczajnego ${ }^{35}$ nadano mu w 1976 r. Od roku akad. 1987/1988 prowadził wykłady z norm generalnych, procesu zwyczajnego i administracyjnego. W 1992 r. został zatrudniony na stanowisku profesora zwyczajnego KUL. Wypromował dziesięciu doktorów, spośród których trzech zostało profesorami na KUL: ks. Stanisław Paździor, ks. abp Andrzej Dzięga i ks. Stanisław Dubiel.

Zakres prac badawczych obejmował historię instytucji prawnych i ius vigens (prawo aktualnie obowiązujące). Podejmował głównie zagadnienia przywilejów królów polskich odnośnie do nominacji biskupich, problematykę dotyczącą powstania i kompetencji urzędu promotora sprawiedliwości w sprawach małżeńskich. Po przejściu w 1993 r. na emeryturę zakończył pracę na KUL. Zmarł 30 października 1995 r. w Lublinie ${ }^{36}$.

Studia z prawa kanonicznego odbył na KUL również ks. Piotr Hemperek $^{37}$. W 1963 r. został zatrudniony na Wydziale Prawa Kanonicznego na stanowisku starszego asystenta w Katedrze Prawa Porównawczego. Funkcję tę pełnił w latach 1963-1965. Od 1965 r. do 1973 r. był adiunktem tej katedry. W 1972 r., po uzyskaniu stopnia doktora habilitowanego, zo-

35 Tytuł nadawany w Polsce do 1990 r. Po 1990 r. wszyscy posiadający taki tytuł otrzymali automatycznie tytuł profesora, zob. Art. 41 ust. 3 ustawy z dnia 12 września 1990 r. o tytule naukowym i stopniach naukowych, Dz. U. z 1990 r. Nr 65, poz. 386: "Tytuły naukowe profesora zwyczajnego i profesora nadzwyczajnego, nadane na podstawie dotychczasowych przepisów, stają się tytułem naukowym profesora, określonym w niniejszej ustawie, z tym że osoby posiadające tytuł profesora zwyczajnego lub profesora nadzwyczajnego zachowują prawo używania nadal tytułów naukowych w dotychczasowym brzmieniu". Zob. szerszej, Profesor nadzwyczajny, https://encyklopedia.pwn.pl/ encyklopedia/profesor\%20nadzwyczajny.html [dostęp: 20.09 .2019 r.]; Profesor, https:// encyklopedia.pwn.pl/haslo/profesor;4009662.html [dostęp: 20.09.2019 r.]; H. Izdebski, J.M. Zieliński, Prawo o szkolnictwie wyższym. Ustawa o stopniach naukowych i tytule naukowym. Komentarz, Warszawa 2013.

36 Zob. tamże, s. 153-154.

37 Biskup Piotr Hemperek (1931-1992), święcenia kapłańskie przyjął w 1955 r.; studia z prawa kanonicznego na Wydziale Prawa Kanonicznego KUL odbył w latach 1955-1958. W 1963 r. uzyskał stopień naukowy doktora prawa kanonicznego, a w 1972 r. - doktora habilitowanego z prawa kanonicznego. W 1982 r. został biskupem pomocniczym lubelskim, zob. S. Tymosz, Piotr Hemperek (1931-1992), [w:] A. Dębiński, W.S. Staszewski, M. Wójcik (red.), Profesorowie prawa..., s. 167-175. 
stał docentem w Katedrze Historii Źródeł i Publicznego Prawa Kościelnego. Od 1973 r. był docentem i kierownikiem Katedry Prawa Publicznego i Źródeł Prawa Kanonicznego. W roku akad. 1980/1981 rozdzielono katedry i został kierownikiem Katedry Źródeł i Literatury Prawa Kanonicznego ${ }^{38}$. Od roku akad. 1983/1984 był kierownikiem Katedry Historii Powszechnego Prawa Kanonicznego. W 1978 r. otrzymał tytuł i stanowisko profesora nadzwyczajnego. Wykładał kościelne prawo publiczne, administrowanie sakramentów i sakramentaliów, historię źródeł i literatury prawa kanonicznego oraz kościelne prawo karne. Pod jego kierunkiem napisano dwie rozprawy doktorskie.

Główne obszary jego badań naukowych stanowiły historia powszechnego prawa kanonicznego i historia kościelnego prawa polskiego, a także relacje państwo-Kościół. Ponadto prowadził badania naukowe z zakresu sakramentów świętych, z wyjątkiem prawa małżeńskiego. Pełnił różne funkcje administracyjne. W latach 1973-1974 był prodziekanem, a w latach 1974-1977 - dziekanem Wydziału Prawa Kanonicznego. W latach 19771980 był prorektorem KUL, a w latach 1983-1986 pełnił funkcję rektora KUL. W 1986 r. został wybrany na rektora na drugą kadencję. Jako rektor wygłosił na dziedzińcu i w auli przemówienia powitalne Ojca św. Jana Pawła II podczas jego wizyty na KUL w 1987 r. Ze względu na stan zdrowia, w 1988 r. złożył rezygnację z urzędu. Zmarł 4 lipca 1992 r. w Zakopanem, a pochowany został w Lublinie na cmentarzu przy ulicy Lipowej ${ }^{39}$.

Wśród przyszłych pracowników naukowych byli też tacy, którzy studiowali równocześnie prawo kanoniczne i świeckie - takim był ks. Stanisław Płodzień ${ }^{40}$. Po uzyskaniu magisterium z prawa, został zatrudniony na Wydziale Prawa i Nauk Społeczno-Ekonomicznych w charakterze młodszego asystenta. W 1948 r. został starszym asystentem Katedry Prawa Rzymskiego, a od 1950 r. - adiunktem przy Katedrze Prawa Kościelnego na tym wydziale. Wykłady prowadził również na Wydziale Nauk

38 Zob. K. Burczak, Katedra Historii Powszechnego Prawa..., s. 394.

39 Zob. S. Tymosz, Piotr Hemperek..., s. 169.

40 Ksiądz Stanisław Płodzień (1913-1962), święcenia kapłańskie przyjął w 1939 r. W 1944 r. rozpoczął studia z prawa, a od 1945 r. z prawa kanonicznego. W 1947 r. ukończył studia z prawa z tytułem zawodowym magistra prawa. W $1948 \mathrm{r}$. uzyskał stopień naukowy doktora nauk prawnych. W 1953 r. uzyskał stopień naukowy doktora prawa kanonicznego. W 1956 r. Centralna Komisja Kwalifikacyjna przyznała mu tytuł naukowy docenta, zob. K. Burczak, Stanistaw Płodzień (1913-1962), [w:] A. Dębiński, W.S. Staszewski, M. Wójcik (red.), Profesorowie prawa..., s. 381-385. 
Humanistycznych i na Wydziale Teologii. Po uzyskaniu w 1953 r. stopnia doktora prawa kanonicznego, w 1954 r. został mianowany zastępcą profesora Katedry Prawa Rzymskiego na Wydziale Prawa Kanonicznego ${ }^{41}$.

Zajęcia dydaktyczne prowadził z prawa rzymskiego oraz z historii starożytnej. Podobnie głównym polem badawczym było prawo rzymskie, a $\mathrm{w}$ nim prawo o zrzucie morskim (Lex Rhodia de iactu) oraz o zakresie kompetencji praktor xenikon, urzędnika egzekucyjnego. W zakresie prawa kanonicznego prowadził badania o querela nullitatis jako środku odwoławczym od wyroków w procesie kanonicznym.

Pełnił na Uniwersytecie różne funkcje administracyjne. W latach 1953-1954 był wicerektorem KUL ds. administracyjnych, zaś w latach 1954-1956 - prorektorem KUL. W tych latach, obok rektora ks. J. Iwanickiego, był budowniczym nowej części Konwiktu Księży Studentów KUL - na budowie uległ wówczas nieszczęśliwemu wypadkowi. Gdy w 1961 r. został dziekanem Wydziału Prawa Kanonicznego, w marcu 1962 r. zaczął odczuwać coraz mocniej konsekwencje tego wypadku. Zmarł 25 marca 1962 r. i został pochowany na cmentarzu przy ulicy Lipowej w Lublinie ${ }^{42}$.

Miały miejsce również takie sytuacje, że kierowano na studia prawa kanonicznego kleryków, którzy następnie kontynuowali studia i podejmowali pracę na wydziale. Taka sytuacja miała miejsce w wypadku ks. Edmunda Przekopa ${ }^{43}$. Po obronie pracy doktorskiej został zatrudniony w Katedrze Prawa Porównawczego jako asystent, a następnie jako adiunkt. Po habilitacji, w 1973 r. został docentem i kierownikiem Katedry Prawa Porównawczego. W 1985 r. nadano mu tytuł profesora nadzwyczajnego. W 1986 r. zrezygnował z pracy na KUL. Prowadził zajęcia dydaktyczne i wykłady z historii kościelnych instytucji katolickich Kościołów wschodnich. Przedmiotem badań naukowych było prawodawstwo katolickich Kościołów wschodnich, szczególnie urząd patriarchy oraz prawo o sakramentach świętych.

41 Podjęcie zajęć na Wydziale Prawa Kanonicznego miało związek z faktem likwidacji przez władze komunistyczne Wydziału Prawa i Nauk Społeczno-Ekonomicznych w 1952 r.

42 Zob. K. Burczak, Stanisław Płodzień..., s. 384.

43 Ksiądz Edmund Przekop (1937-1999), święcenia kapłańskie przyjął w 1960 r. Jako kleryk, z powodu braku wieku do święceń, został skierowany na KUL na studia z prawa kanonicznego. Po przyjęciu święceń ponownie został posłany na studia i ukończył je w 1964 r. z tytułem zawodowym magistra prawa kanonicznego. Doktorat obronił na KUL, zaś stopień doktora habilitowanego uzyskał w 1973 r., zob. G. Wojciechowski, Edmund Przekop (19371999), [w:] A. Dębiński, W.S. Staszewski, M. Wójcik (red.), Profesorowie prawa..., s. 393-398. 
Wśród profesorów wywodzących się z innych ośrodków naukowych pracę na KUL rozpoczął po wojnie Leon Halban ${ }^{44}$. Pracę rozpoczął w 1944 r. W tym roku został profesorem nadzwyczajnym, a w 1945 r. profesorem zwyczajnym prawa kanonicznego ${ }^{45}$. Od tego roku był kierownikiem Katedry Prawa Kościelnego Publicznego, Historii Źródeł i Metodologii na Wydziale Prawa Kanonicznego. Stąd przedmiotem jego wykładów była historia źródeł prawa kanonicznego, metodologia historyczno-prawna, administracja wyznaniowa oraz publiczne prawo kościelne. Równocześnie na Wydziale Prawa i Nauk Społeczno-Ekonomicznych był kierownikiem Katedry Historii Ustroju Polski i Prawa Polskiego oraz Historii Prawa na Zachodzie Europy. Główne pola badawcze to historia prawa kościelnego oraz doktryna Kościoła katolickiego, zagadnienia społeczne w prawie kanonicznym, relacje Kościół-państwo. Pracę na KUL zakończył w 1949 r. i odtąd pracował na UMCS. Zmarł 3 maja 1960 r.

Absolwentem Wydziału Prawa Kanonicznego był ks. Kazimierz Nasiłowski. Pracę na Wydziale rozpoczął w roku akad. 1952/1953. Wykładał historię źródeł i literatury prawa kanonicznego i prowadził ćwiczenia. W 1958 r. wyjechał do RFN na stypendium naukowe ${ }^{46}$. Do pracy na wydziale powrócił w 1962 r. i prowadził ćwiczenia z historii źródeł i literatury prawa kanonicznego, w roku akad. 1965/1966 - wykład i ćwiczenia. W 1966 r. zakończył pracę na wydziale ${ }^{47}$.

Na Wydziale Prawa Kanonicznego pracował również ks. Franciszek Wycisk. Od 1963 r. był asystentem w Katedrze Prawa Rzymskiego, a od 1969 r. - adiunktem. Od roku akad. 1969/1970 prowadził wykład z historii prawa kanonicznego. W roku akad. 1971/1972 otrzymał urlop naukowy. W następnym roku prowadził wykład z historii źródeł prawa kanonicznego, podobnie w roku akad. 1974/1975 - z historii źródeł i literatury prawa kanonicznego (aż do 1977 r.). Na wydziale pracował w latach 1963-197748.

44 Leon Halban (1893-1960), doktorat uzyskał na Uniwersytecie Jana Kazimierza we Lwowie w 1916 r., zaś w 1926 r. - stopień naukowy doktora habilitowanego na tej samej uczelni, zob. L. Ćwikła, Leon Halban (1893-1960), [w:] A. Dębiński, W.S. Staszewski, M. Wójcik (red.), Profesorowie prawa..., s. 159-166.

45 Na Uniwersytecie Jana Kazimierza we Lwowie był profesorem tytularnym od 1932 r., a od 1936 r. był profesorem nadzwyczajnym prawa kanonicznego.

46 Zob. K. Burczak, Katedra Historii Powszechnego Prawa..., s. 394.

47 Zob. tamże, s. 408.

48 Zob. tamże, s. 404. 
Pracownikiem wydziału był także ks. Józef Bakalarz. W 1974 r. został on asystentem przy Katedrze Prawa Publicznego i Źródeł Prawa Kanonicznego, a od 1980 r. - adiunktem przy katedrze Źródeł i Literatury Prawa Kanonicznego. Pracę na stanowisku adiunkta w Katedrze Historii Powszechnego Prawa Kanonicznego zakończył w 1989 r. ${ }^{49}$

W 1969 r. pracował jako stażysta ks. Antoni Okrzesik. W roku akad. 1970/1971 prowadził ćwiczenia z historii źródeł prawa kanonicznego. Był on absolwentem Wydziału Prawa Kanonicznego. Pracę na wydziale zakończył w 1975 r. ${ }^{50}$

Ćwiczenia w roku akad. 1990/1991 prowadził ks. Sławomir Nasiorowski. On też prowadził wykład z historii powszechnego prawa kanonicznego dla studentów zaocznych ${ }^{51}$. Obecnie jest pracownikiem Sekretariatu Stanu Stolicy Apostolskiej.

Kanonistyczne wykształcenie uzyskał na KUL o. Wenanty Bronisław Zubert $^{52}$. Pracę na Wydziale Prawa Kanonicznego rozpoczął w 1963 r. jako asystent. Jako doktor prawa kanonicznego w latach 1970-1972, 1983 i 1996 był stypendystą Fundacji im. Humboldta w Instytucie Prawa Kanonicznego na Wydziale Teologii Ludwig-Maximilians-Universität w Monachium. Jako adiunkt prowadził wykłady z prawa zakonnego (pocz. roku akad. 1970/1971). Docentem został w 1983 r. Po powstaniu w 1984 r. Wydziału Prawa Kanonicznego i Nauk Prawnych z II Katedry Tekstu Prawa Kanonicznego powstała Katedra Instytutów Życia Zakonnego i Stowarzyszeń Życia Apostolskiego. Został wówczas jej kierownikiem. Od 1984 r. prowadził również wykłady z prawa sakramentów i był kuratorem Katedry Prawa Sakramentów (do 2008 r.). W latach 1996-1998 wykładał prawo zakonne i prawo o sakramentach w Spiskiej Kapitule na Słowacji oraz w latach 1998-2000 - w Welehradzie w Czechach. Prawo zakonne, prawo o sakramentach oraz prawo małżeńskie stanowiły główny przedmiot jego wykładów. Pod jego kierunkiem powstało jedenaście prac doktorskich, $\mathrm{w}$ tym siedem prac doktorskich z zakresu prawa o sakramentach. Pracę

49 Zob. tamże.

50 Zob. tamże, s. 408.

51 Zob. tamże, s. 401.

52 Ojciec Wenanty Bronisław Zubert (1935-2015), święcenia kapłańskie przyjął w 1958 r.; stopień naukowy doktora prawa kanonicznego uzyskał w 1967 r., a stopień doktora habilitowanego w 1981 r. W 1992 r. otrzymał tytuł profesora, zob. A. Skorupa, Katedra Prawa Instytutów Życia Konsekrowanego i Stowarzyszeń Życia Apostolskiego, [w:] A. Dębiński i in. (red.), Księga Jubileuszowa z okazji 90-lecia Wydziału..., s. 512-513. 
etatowego wykładowcy zakończył 30 września 2009 r. W następnym roku prowadził zajęcia dydaktyczne $\mathrm{w}$ ramach umowy o dzieło i ostatecznie zakończył pracę na KUL. Zmarł 30 maja 2015 r. w Afiartis na greckiej wyspie Karpathos ${ }^{53}$.

Studia kanonistyczne odbył na KUL ks. Stanisław Paździor ${ }^{54}$. Pracę na Wydziale Prawa Kanonicznego i Świeckiego rozpoczął w 1994 r. jako asystent. Od 1999 r. był adiunktem i kierownikiem Katedry Kościelnego Prawa Małżeńskiego i Rodzinnego. Od 2001 r. był kierownikiem Katedry Prawa Kanonicznego na Wydziale Zamiejscowym Nauk Prawnych i Ekonomicznych KUL w Tomaszowie Lubelskim. W 2014 r. został pracownikiem Katedry Kościelnego Prawa Procesowego. Zajęcia dydaktyczne prowadził głównie z prawa kanonicznego małżeńskiego i procesowego. Podobnie zakres badań naukowych dotyczył prawa małżeńskiego, w tym psychiczna zdolność bądź niezdolność do zawarcia małżeństwa, poważny brak rozeznania oceniającego co do istotnych praw i obowiązków małżeńskich wzajemnie przekazywanych i przyjmowanych ${ }^{55}$. Zmarł w Sokołowie Podlaskim 9 sierpnia 2015 r.

\section{Wydział Prawa Kanonicznego i Nauk Prawnych}

Staraniem ks. prof. Józefa Krukowskiego na Wydziale Prawa Kanonicznego w 1981 r. reaktywowano sekcję prawa, która faktycznie zaczęła funkcjonować od roku akad. 1983/1984. Odtąd istniały dwie sekcje: Sekcja Prawa Kanonicznego i Sekcja Prawa. Wydział przyjął nazwę Wydział Prawa Kanonicznego i Nauk Prawnych ${ }^{56}$.

53 Zob. W. Bar, E. Szczot, Dydaktyka i badania z zakresu prawa kanonizacyjnego oraz sakramentów świętych, [w:] K. Burczak i in. (red.), 100 lat nauk prawnych na Katolickim Uniwersytecie Lubelskim Jana Pawła II, Lublin 2018, s. 410-413.

54 Ksiądz Stanisław Paździor (1946-2015), święcenia kapłańskie przyjął w 1970 r.; stopień naukowy doktora prawa kanonicznego uzyskał w 1979 r., natomiast stopień doktora habilitowanego w 1999 r. Tytuł naukowy profesora otrzymał w 2007 r., zob. M. Greszata-Telusiewicz, Katedra Kościelnego Prawa Procesowego, [w:] K. Burczak i in. (red.), 100 lat nauk prawnych na Katolickim Uniwersytecie Lubelskim Jana Pawła II, Lublin 2018, s. 314-315.

55 Zob. M. Greszata-Telusiewicz, Katedra Kościelnego Prawa Procesowego, [w:] K. Burczak i in. (red.), 100 lat nauk prawnych..., s. 315-316.

56 Zob. A. Dębiński i in. (red.), Informator..., s. 19. 
Ksiądz Józef Krukowski należy do profesorów, którzy tworzyli historię Wydziału i którym dziś możemy wyrazić za to wdzięczność ${ }^{57}$. Pracę na KUL rozpoczął w 1964 r. jako asystent. W 1983 r. został kierownikiem Katedry Kościelnego Prawa Publicznego i Konstytucyjnego - funkcję tę pełnił do 2009 r. W latach 1983-2013 r. wykładał kościelne prawo publiczne (z przerwą od 2006 do 2009 r.). W latach 1978-1987 pełnił funkcję dziekana wydziału. Badania naukowe prowadzi w wielu obszarach prawa kanonicznego, szczególnie kościelnego prawa publicznego, prawa wyznaniowego, z zakresu stosunków pomiędzy państwem i Kościołem, kościelnego prawa administracyjnego. Wniósł wielki wkład w przywrócenie od 1983 r. nauczania prawa świeckiego na KUL. Prowadził wykłady na wielu uniwersytetach w Stanach Zjednoczonych i Kanadzie, Ukrainie, na Słowacji i w Czechach. Jest organizatorem kongresów prawa kanonicznego oraz konferencji. Ponadto jest założycielem wielu stowarzyszeń, Kanonistów Polskich, Absolwentów i Przyjaciół Wydziału Prawa Katolickiego Uniwersytetu Lubelskiego. W latach 1990-1993 był członkiem Centralnej Komisji ds. Stopni i Tytułów. Od 1985 r. jest konsultorem Papieskiej Rady ds. Tekstów Prawnych. Jest też założycielem Roczników Nauk Prawnych ${ }^{58}$. Dorobek naukowy stanowi ponad 750 prac.

Prawem kanonizacyjnym zajmował się ks. Henryk Misztal ${ }^{59}$. Na Wydziale Prawa Kanonicznego został zatrudniony w 1969 r. jako straszy asystent. Od 1979 r. był adiunktem, a od 1980 r. - docentem. W 1980 r. był kuratorem Katedry Prawa Wyznaniowego, a od 1984 r. - Katedry Prawa Kanonizacyjnego. Zajęcia dydaktyczne prowadził z prawa pracy

57 Ksiądz Józef Krukowski, urodził się 4 stycznia 1936 r. w Sułowcu k. Zamościa. Święcenia kapłańskie przyjął w 1959 r. W latach 1961-1964 studiował prawo kanoniczne na KUL. Stopień naukowy doktora nauk prawnych w zakresie prawa kanonicznego uzyskał w 1968 r., a w 1973 r. - stopień doktora habilitowanego. W 1978 r. otrzymał tytuł profesora nadzwyczajnego, a w 1985 r. - profesora zwyczajnego, zob. W. Kacprzyk, Katedra Kościelnego Prawa Publicznego i Konstytucyjnego, [w:] A. Dębiński i in. (red.), Księga Jubileuszowa z okazji 90-lecia Wydziatu..., s. 509.

58 Zob. M. Sitarz, Katedra Kościelnego Prawa Publicznego i Konstytucyjnego, [w:] K. Burczak $\mathrm{i}$ in. (red.), 100 lat nauk prawnych..., s. 346, 349, 351, 354, 358.

59 Ksiądz Henryk Misztal, urodził się 10 kwietnia 1936 r. we wsi Skubicha k. Lublina. Święcenia kapłańskie przyjął w 1960 r. W latach 1961-1964 odbył studia na Wydziale Prawa Kanonicznego KUL. Stopień naukowy doktora prawa kanonicznego uzyskał w 1968 r., natomiast stopień doktora habilitowanego w 1979 r. Profesorem nadzwyczajnym został w 1986 r., a zwyczajnym w 1992 r., zob. A. Abramowicz, P. Stanisz, Katedra Prawa Wyznaniowego, [w:] K. Burczak i in. (red.), 100 lat nauk prawnych..., s. 151-152, przyp. 510. 
i ubezpieczeń społecznych, prawa rodzinnego i opiekuńczego, prawa administracyjnego, cywilnego i wyznaniowego, procesu kanonicznego, czasów i miejsc świętych, prawa do nauczania religii w szkole i prawa kanonizacyjnego. Prowadził też wykład fakultatywny w języku włoskim. Wykłady z prawa kanonizacyjnego i wyznaniowego prowadził również na Słowacji, w Czechach, na Litwie, w Stanach Zjednoczonych. Główne pola badawcze stanowiły prawo kanonizacyjne i prawo wyznaniowe, szczególnie zagadnienie spraw historycznych w postępowaniach beatyfikacyjnych i kanonizacyjnych, procedura kanonizacyjna i rola biegłych ${ }^{60}$. W latach 1983-1987 był prodziekanem, a w latach 1987-1989 - dziekanem Wydziału Prawa Kanonicznego i Świeckiego. Wypromował 32 doktorów, 16 z prawa wyznaniowego.

\section{Wydział Prawa Kanonicznego i Świeckiego}

W 1989 r. nastąpiła zmiana nazwy wydziału na Wydział Prawa Kanonicznego i Świeckiego. Od tego roku funkcję dziekana objął ks. prof. Marian Stasiak. Jest on jednym z profesorów wykształconych na wydziale ${ }^{61}$. Pracę na KUL rozpoczął w 1974 r. Od 1986 r. był kierownikiem Katedry Teologii i Norm Ogólnych Prawa Kanonicznego. W latach 1989-1999 był dziekanem Wydziału Prawa Kanonicznego i Świeckiego KUL. Wygłaszał referaty na Międzynarodowym Kongresie Prawa Kanonicznego w Paryżu w 1990 r. i Mexico City w 1995 r. Był organizatorem VIII Międzynarodowego Kongresu Kościót - Państwo we wspótczesnych systemach prawnych w 1993 r. w Lublinie. Aktywnie uczestniczył w powstaniu Wydziału Zamiejscowego Nauk Prawnych i Ekonomicznych KUL w Tomaszowie Lubelskim, a także studiów z prawa kanonicznego w Spiskiej Kapitule na Słowacji i w Ołomuńcu w Czechach. Obszar badań naukowych stanowią ontologiczne podstawy porządku prawnego Kościoła, eklezjologiczna na-

60 Zob. L. Fiejdasz, Katedra Prawa Kanonizacyjnego, [w:] A. Dębiński i in. (red.), Ksiegga Jubileuszowa z okazji 90-lecia Wydziału..., s. 525-528.

61 Ksiądz Marian Stasiak, urodził się 5 czerwca 1942 r. w Garbowie. Święcenia kapłańskie przyjął w 1966 r. Stopień doktora prawa kanonicznego uzyskał na papieskim Uniwersytecie Gregoriańskim w Rzymie w 1974 r., natomiast stopień doktora habilitowanego w 1984 r., zob. A. Kaczor, Katedra Teologii i Norm Ogólnych Prawa Kanonicznego, [w:] A. Dębiński i in. (red.), Księga Jubileuszowa z okazji 90-lecia Wydziału..., s. 585-586. 
tura władzy i struktur hierarchicznych, specyfika norm generalnych i reguły interpretacyjne Kodeksu Prawa Kanonicznego. Pracę na KUL zakończył w 2013 r.

Kolejnym profesorem prawa kanonicznego wykształconym na KUL jest ks. Wojciech Góralski' ${ }^{62}$. Pracę na Wydziale Prawa Kanonicznego KUL rozpoczął w 1977 r. na stanowisku adiunkta w Katedrze Historii Źródeł Kościelnego Prawa Polskiego. Od 1978 r. był docentem wykładając ponadto prawo o sakramentach i metodologię prawa kanonicznego. W 1985 r. został kierownikiem Katedry Kościelnego Prawa Małżeńskiego i Rodzinnego, a w 1989 r. - kierownikiem Sekcji Prawa Kanonicznego na Wydziale Prawa Kanonicznego i Świeckiego. W 1996 r. zakończył pracę na KUL. Wypromował 24 doktorów. Główne pola badawcze to historia instytucji prawa kanonicznego i historia ustawodawstwa kościelnego. Wśród nich szczególnie kapituły katedralne i kolegiackie, ustawodawstwo synodalne, kodyfikacja prawa. Ważnym obszarem jest też kanoniczne prawo małżeńskie i rodzinne. W tym zakresie zagadnienie niezdolności do podjęcia istotnych obowiązków małżeńskich. Kolejne pole badawcze to prawo konkordatowe ${ }^{63}$.

W 1985 r. w Katedrze Prawa Rzymskiego na stanowisku asystenta został zatrudniony ks. Antoni Dębiński. Od 1991 r. był adiunktem, a od 1998 r. - profesorem nadzwyczajnym. Prowadził wykład z prawa rzymskiego dla studentów prawa i prawa kanonicznego. Od roku akad. 1996/1997 był kuratorem Katedry Historii Powszechnego Prawa Kanonicznego i z tego przedmiotu w latach 1993-2005 prowadził wykład, a w latach 1993-1997 - również ćwiczenia i proseminarium.

Prawem procesowym zajmuje się wykształcony na KUL abp Andrzej Dzięga $^{64}$. Pracę na wydziale rozpoczął w 1989 r. W 1996 r. został kierow-

62 Ksiądz Wojciech Góralski urodził się 19 lutego 1939 r. w Poznaniu. Święcenia kapłańskie przyjął w 1961 r. W 1965 r. uzyskał stopień naukowy doktora nauk prawnych w zakresie prawa kanonicznego, natomiast w 1977 r. - stopień doktora habilitowanego. Tytuł naukowy profesora nadzwyczajnego otrzymał w 1983 r., a tytuł profesora zwyczajnego w 1989 r., zob. K. Burczak, Uroczystość odnowienia doktoratu ks. prof. dra hab. Wojciecha Góralskiego, Lublin 2015, s. 12-17.

63 Zob. tamże, s. 22-27.

64 Arcybiskup Andrzej Dzięga, urodził się 14 grudnia 1952 r. w Radzyniu Podlaskim; święcenia kapłańskie przyjął w 1977 r. Stopień doktora nauk prawnych w zakresie prawa kanonicznego uzyskał w 1988 r., natomiast stopień doktora habilitowanego w 1995 r. W 2002 r. został biskupem sandomierskim, a w 2009 r. - arcybiskupem metropolitą szczecińsko-kamieńskim, zob. M. Greszata-Telusiewicz, Katedra Kościelnego Prawa Procesowego, [w:] K. Burczak i in. (red.), 100 lat nauk prawnych..., s. 310-311. 
nikiem Katedry Kościelnego Prawa Procesowego. W latach 1996-2001 był kuratorem Katedry Kościelnego Prawa Małżeńskiego i Rodzinnego, a od 2001 r. - Katedry Kościelnego Prawa Karnego. Pełnił też funkcje administracyjne. Od 1996 r. był prodziekanem, a od 1999 r. do 2004 r. - dziekanem Wydziału Prawa, Prawa Kanonicznego i Administracji. W 2009 r. został kierownikiem Katedry Prawa Rodzinnego i Prawa Rodziny. Pracę na wydziale zakończył w 2004 r. Przedmiotem zajęć dydaktycznych były normy generalne oraz kościelne prawo procesowe i prawo rodzinne. Praca badawcza dotyczy zakresu prawa procesowego, a szczególnie przebiegu procedury sądowego procesu ustnego oraz uprawnień stron procesowych w kanonicznym procesie o nieważność małżeństwa, a także innych osób w kanonicznym procesie spornym. Kolejnym polem badawczym jest polskie prawo rodzinne. Dotychczas był promotorem 15 doktoratów ${ }^{65}$.

Prawem karnym zajmował się ks. Florian Lempa ${ }^{66}$. Pracę na wydziale rozpoczął w 1984 r. W latach 1993-1996 był kierownikiem Katedry Kościelnego Prawa Karnego. Przedmiotem zajęć dydaktycznych było prawo karne. Obszary badań to w zakresie prawa karnego odpowiedzialność za przestępne nadużycie władzy kościelnej, prawna ochrona życia poczętego oraz kary za poszczególne przestępstwa ${ }^{67}$. Pracę na KUL zakończył w 1996 r.

Zajęcia z zakresu prawa karnego podjął ks. Zbigniew Podlecki ${ }^{68}$. Został zatrudniony w 1995 r. Badania naukowe prowadził w zakresie prawa karnego i nauczycielskich zadań Kościoła. Przedmiotem badań naukowych była też ochrona życia ludzkiego w kanonicznym i świeckim prawie karnym ${ }^{69}$.

Zajęcia dydaktyczne prowadził również ks. Ryszard Sztychmiler ${ }^{70}$. Pracę na Wydziale Prawa Kanonicznego i Świeckiego rozpoczął w 1986 r.

65 Zob. tamże, s. 312-313.

${ }^{66}$ Ksiądz Florian Lempa urodził się 7 maja 1951 r. w Kochcicach. Święcenia kapłańskie przyjął w 1978 r. Stopień doktora prawa kanonicznego uzyskał w 1984 r., natomiast stopień doktora habilitowanego - w 1992 r., zob. A.G. Miziński, Katedra Kościelnego Prawa..., s. 450 .

67 Zob. tamże, s. 445.

68 Ksiądz Zbigniew Podlecki urodził się 10 maja 1959 r. w Braniewie. Stopień doktora prawa kanonicznego uzyskał na Uniwersytecie Navarra w Pamplonie, a nostryfikował w 1997 r. na KUL, zob. A.G. Miziński, Katedra Kościelnego Prawa..., s. 451.

69 Zob. tamże, s. 446.

70 Ksiądz Ryszard Sztychmiler urodził się 12 kwietnia 1948 r. w Pasłęku. Święcenia kapłańskie przyjął w 1972 r. Stopień naukowy doktora prawa kanonicznego uzyskał w 1982 r., natomiast stopień doktora habilitowanego - w 1994 r. Tytuł profesora otrzymał 
W latach 1986-87 był asystentem, a w latach 1988-1994 - adiunktem. Powadził zajęcia z kościelnego prawa małżeńskiego oraz z kościelnego prawa publicznego. Wykładał procesy specjalne, a także metodologię prawa kanonicznego i metodykę pisania pracy naukowej. Obszar badań stanowi posoborowe ustawodawstwo małżeńskie, w tym cele małżeństwa w świetle nauki Soboru Watykańskiego II i ustawodawstwo posoborowe. Pracę na KUL zakończył w 1994 r.

Po zakończeniu pracy na wydziale ks. prof. Wojciecha Góralskiego, od 1997 r. został zatrudniony na stanowisku asystenta ks. Stanisław Tymosz ${ }^{71}$. Prowadził zajęcia z historii źródeł kościelnego prawa polskiego. Od 1999 r. pracował na stanowisku adiunkta. Od 2003 r. był kierownikiem Katedry Historii Źródeł Kościelnego Prawa Polskiego. Od 2004 r. był dyrektorem Instytutu Prawa Kanonicznego. Badania naukowe prowadził w obszarze synodów archidiecezji gnieźnieńskiej i lwowskiej w okresie przedrozbiorowym, synodów diecezjalnych i plenarnych w Polsce ${ }^{72}$. Pracę na KUL zakończył w 2013 r.

Pracownikiem wydziału był ks. Stanisław Dubiel ${ }^{73}$. Został zatrudniony w 1993 r. jako asystent przy Katedrze Kościelnego Prawa Małżeńskiego i Rodzinnego. Od 2008 r. był kierownikiem Katedry Kościelnego Prawa Majątkowego. Funkcję tę pełnił do 2017 r., do czasu przejścia na emeryturę. Badania naukowe prowadził w obszarze roli i zadań zarządców majątku kościelnego, fundacji kościelnych, alienacji majątku kościelnego i utrzymania duchownych ${ }^{74}$.

Wśród pracowników prowadzących działalność dydaktyczną i naukową z prawa kanonicznego jest ks. Sylwester Kasprzak ${ }^{75}$, który aktual-

w 1999 r., zob. T. Syczewski, Katedra Kościelnego Prawa Małżéskiego i Rodzinnego, [w:] A. Dębiński i in. (red.), Księga Jubileuszowa z okazji 90-lecia Wydziału..., s. 458-459.

71 Ksiądz Stanisław Tymosz urodził się 29 kwietnia 1957 r. w Przemyślu. Święcenia kapłańskie przyjął w 1983 r. Stopień doktora prawa kanonicznego uzyskał w 1996 r., zob. A. Dębiński i in. (red.), Informator..., s. 78.

72 Zob. S. Tymosz, Katedra Historii Źródet Kościelnego Prawa Polskiego, [w:] A. Dębiński $\mathrm{i}$ in. (red.), Księga Jubileuszowa z okazji 90-lecia Wydziału..., s. 426.

73 Ksiądz Stanisław Dubiel urodził się 15 maja 1947 r. w Dzwoli. Święcenia kapłańskie przyjął w 1971 r. Stopień doktora prawa kanonicznego uzyskał w 1993 r., natomiast stopień doktora habilitowanego - w 2007 r., zob. A Dębiński i in. (red.), Informator..., s. 89.

${ }^{74}$ P. Kaleta, Katedra Norm Ogólnych i Kościelnego Prawa Majątkowego, [w:] K. Burczak $\mathrm{i}$ in. (red.), 100 lat nauk prawnych..., s. 327.

75 Ksiądz Sylwester Kasprzak urodził się 2 listopada 1959 r. w Gnieźnie. Święcenia kapłańskie przyjął w 1986 r. Stopień naukowy doktora uzyskał w 1993 r., natomiast stopień 
nie zatrudniony jest w Instytucie Administracji Wydziału Prawa, Prawa Kanonicznego i Administracji KUL. Na Wydziale zatrudniony został w 1997 r. W 1999 r. został adiunktem w Katedrze Teologii i Norm Ogólnych Prawa Kanonicznego. Jego badania naukowe dotyczą urzędu, historii i zadań Kardynała Kamerlinga Świętego Kościoła Rzymskiego oraz teologicznych podstaw prawa kanonicznego.

Pracownikiem naukowym w Katedrze Kościelnego Prawa Publicznego i Konstytucyjnego był ks. Krzysztof Orzeszyna. Pracę na wydziale rozpoczął w 1999 r. Po uzyskaniu stopnia doktora habilitowanego w 2008 r. został kierownikiem Katedry Praw Człowieka w Instytucie Prawa.

Na wydziale pracowali również: ks. Jacek Jaśkowski, w latach 20032007 jako asystent doktorant w Katedrze Prawa Sakramentów Świętych; ks. Kazimierz Gajda, w latach 1996-2000, 2000-2003 na podstawie umowy o dzieło, jako asystent w Katedrze Prawa Kanonizacyjnego; ks. Wiesław Kacprzyk od roku akad. 2004/2005 do 2006/2007 w Katedrze Kościelnego Prawa Publicznego i Konstytucyjnego - prowadził ćwiczenia; ks. Mirosław Wróbel rozpoczął pracę na wydziale w 2002 r., a zakończył w 2006 w Katedrze Kościelnego Prawa Procesowego. W tej katedrze pracował również ks. Krzysztof Graczyk, ks. Zdzisław Jancewicz, ks. Szymon Pikus.

W roku akad. 1998/1999 ćwiczenia z Historii Powszechnego Prawa Kanonicznego dla kursu B prowadziła mgr Magdalena Pyter. Obecnie pracuje w Instytucie Administracji WPPKiA.

W 1989 r. zaniechano podziału na dwie sekcje i kierunek prawo kanoniczne znalazł się w Instytucie Prawa Kanonicznego ${ }^{76}$.

\section{Wydział Prawa, Prawa Kanonicznego i Administracji}

W 1999 r. utworzono nowy kierunek studiów - administracja. Wówczas dokonano kolejnej zmiany nazwy wydziału na Wydział Prawa, Prawa Kanonicznego i Administracji, która to nazwa funkcjonuje do chwili obecnej.

doktora habilitowanego - w 2009 r., zob. A. Kaczor, Katedra Teologii i Norm Ogólnych..., s. 586 .

76 Zob. S. Jóźwiak, Prawo kanoniczne w strukturach Katolickiego Uniwersytetu Lubelskiego, [w:] A. Dębiński i in. (red.), Księga Jubileuszowa z okazji 90-lecia Wydziału..., s. 391. 
Prawo kanoniczne studiowano:

- na Kursie A - trzyletnie studia dzienne dla osób z wykształceniem teologicznym;

- na Kursie B - studia dzienne pięcioletnie i studia zaoczne czteroletnie dla osób z wykształceniem teologicznym.

W 2005 r. prawo kanoniczne studiowały 262 osoby.

W 2005 r. W Instytucie Prawa Kanonicznego było 11 katedr:

- Katedra Historii Źródeł Kościelnego Prawa Polskiego,

- Katedra Historii Powszechnego Prawa Kanonicznego,

- Katedra Teologii i Norm Ogólnych Prawa Kanonicznego,

- Katedra Kościelnego Prawa Karnego,

- Katedra Kościelnego Prawa Małżeńskiego i Rodzinnego,

- Katedra Kościelnego Prawa Publicznego i Konstytucyjnego,

- Katedra Prawa Katolickich Kościołów Wschodnich,

- Katedra Prawa Instytutów Życia Konsekrowanego i Stowarzyszeń Życia Apostolskiego,

- Katedra Prawa Sakramentów Świętych,

- Katedra Kościelnego Prawa Procesowego,

- Katedra Prawa Kanonizacyjnego ${ }^{77}$.

W 2008 r. utworzono Katedrę Kościelnego Prawa Majątkowego, która od 2014 r. została połączona z Katedrą Teologii i Norm Ogólnych Prawa Kanonicznego.

Aktualna struktura Instytutu Prawa Kanonicznego obejmuje sześć katedr:

- Katedra Historii Prawa Kanonicznego (bp dr hab. Artur Grzegorz Niziński; ks. dr hab. Tadeusz Syczewski; ks. dr hab. Krzysztof Burczak, prof. KUL; ks. dr Adam Jaszcz,

- Katedra Kościelnego Prawa Procesowego (dr hab. Marta Greszata-Telusiewicz, prof. KUL; ks. dr Grzegorz Bzdyrak; ks. dr Wojciech Witkowski),

- Katedra Kościelnego Prawa Publicznego i Konstytucyjnego (ks. dr hab. Mirosław Sitarz, prof. KUL; dr Agnieszka Romanko; dr Anna Słowikowska),

- Katedra Norm Ogólnych i Kościelnego Prawa Majątkowego (ks. dr hab. Ambroży Skorupa, prof. KUL; ks. dr Adam Kaczor; ks. dr Paweł Kaleta),

77 A. Dębiński i in. (red.), Informator..., s. 52. 
- Katedra Prawa Kanonizacyjnego i Sakramentów Świętych (prof. dr hab. Wiesław Bar; dr hab. Elżbieta Szczot, prof. KUL; dr Lidia Fiejdasz-Buczek),

- Katedra Prawa Katolickich Kościołów Wschodnich (ks. dr hab. dr h. c. Leszek Adamowicz; ks. dr hab. Krzysztof Mikołajczuk; ks. dr hab. Grzegorz Wojciechowski).

\section{Funkcje kościelne profesorów prawa kanonicznego KUL}

- bp Jan Nowicki (zm. 1973 r.) - administrator apostolski w Lubaczowie,

- bp Piotr Kałwa (zm. 1974 r.) - biskup lubelski,

- bp Walenty Wójcik (zm. 1990 r.) - biskup pomocniczy diecezji sandomierskiej,

- abp Andrzej Dzięga - od 2002 r. biskup sandomierski, od 2009 r. arcybiskup metropolita szczecińsko-kamieński,

- bp Artur Grzegorz Miziński - od 2004 r. biskup pomocniczy lubelski, od 2014 r. Sekretarz Generalny Konferencji Episkopatu Polski.

\section{Doktorzy honoris causa}

- o. prof. Bronisław Wenanty Zubert - Katolicki Uniwersytet im. Pétera Pázmánya w Budapeszcie, 2011 r.,

- abp Andrzej Dzięga - Katolicki Uniwersytet im. Pétera Pázmánya w Budapeszcie, 2014 r.,

- ks. prof. dr hab. Leszek Adamowicz - Uniwersytet w Preszowie na Słowacji, $2017 \mathrm{r}$.

\section{Zakończenie}

100 lat Prawa Kanonicznego na Katolickim Uniwersytecie Lubelskim Jana Pawta II daje obraz bezcennego wysiłku badawczego, dydaktycznego i organizacyjnego. Prawo kanoniczne porządkujące życie społeczności Kościoła wymaga naukowego dyskursu i podążania za szybkim rytmem życia. Zasada ius sequitur vitam dotyczy też prawa kanonicznego. Zmieniające się 
wymogi życia wywołują u ustawodawcy konieczność regulacji prawnych. Stąd w tych 100 latach przyjęto dwa Kodeksy Prawa Kanonicznego (1917 i 1983 r.), których kanony stały się podstawą refleksji naukowej oraz która zaowocowała naukowymi komentarzami. W ich przygotowaniu brali czynny udział profesorowie Wydziału Prawa Kanonicznego. Autorstwa profesorów wydziału są niezliczone hasła w encyklopediach i leksykonach. Wygłoszone na kongresach i konferencjach referaty są świadectwem aktywnego uczestnictwa profesorów w życiu naukowym. Stanowią też istotny wkład w promocję Uniwersytetu. Pracownicy wydziału kształcili kapłanów i osoby świeckie z wielu krajów m.in. Ukrainy, Słowacji, Czech, Białorusi, Litwy. Zaangażowanie naszych profesorów w przygotowanie różnych aktów prawnych kościelnych i państwowych dowodzi uznanego autorytetu środowiska kanonistów KUL. Dziś, gdy dziękujemy Bogu za dar 100 lat istnienia Uniwersytetu i wydziału chcemy wyrazić wdzięczność za ich intelektualny trud. Czerpiąc najlepsze wzorce, chcemy nie zapomnieć o ich naukowym wysiłku i stosownie do umiejętności, kontynuować służbę Deo et Patriae.

Słowa kluczowe: prawo kanoniczne, uniwersytet, wydział, instytut, katedra, jubileusz

\section{Bibliografia}

Abramowicz A., P. Stanisz, Katedra Prawa Wyznaniowego, [w:] K. Burczak i in. (red.), 100 lat nauk prawnych na Katolickim Uniwersytecie Lubelskim Jana Pawła II, Lublin 2018, s. 149-180.

Adamowicz L., Pawet Pałka (1904-1992), [w:] A. Dębiński, W.S. Staszewski, M. Wójcik (red.), Profesorowie prawa Katolickiego Uniwersytetu Lubelskiego, Lublin 2008, s. 335-339.

Bar W., Aleksy Petrani (1900-1977), [w:] A. Dębiński, W.S. Staszewski, M. Wójcik (red.), Profesorowie prawa Katolickiego Uniwersytetu Lubelskiego, Lublin 2008, s. 373-379.

Bar W., E. Szczot, Dydaktyka i badania z zakresu prawa kanonizacyjnego oraz sakramentów świętych, [w:] K. Burczak i in. (red.), 100 lat nauk prawnych na Katolickim Uniwersytecie Lubelskim Jana Pawta II, Lublin 2018, s. 391-416.

Burczak K., Bronistaw Żongołłowicz (1870-1944), [w:] A. Dębiński, W.S. Staszewski, M. Wójcik (red.), Profesorowie prawa Katolickiego Uniwersytetu Lubelskiego, Lublin 2008, s. 549-559. 
Burczak K., Katedra Historii Powszechnego Prawa Kanonicznego, [w:] A. Dębiński i in. (red.), Ksiega Jubileuszowa z okazji 90-lecia Wydziatu Prawa, Prawa Kanonicznego i Administracji Katolickiego Uniwersytetu Lubelskiego Jana Pawta II, Lublin 2008, s. 393-411.

Burczak K., Stanisław Płodzień (1913-1962), [w:] A. Dębiński, W.S. Staszewski, M. Wójcik (red.), Profesorowie prawa Katolickiego Uniwersytetu Lubelskiego, Lublin 2008, s. 381-386.

Burczak K., Uroczystość odnowienia doktoratu ks. prof. dra hab. Wojciecha Góralskiego, Lublin 2015, s. 12-17.

Burczak K., E. Czepczyńska, M. Dyjakowska, M. Jońca, S. Kwiecień (red.), 100 lat nauk prawnych na Katolickim Uniwersytecie Lubelskim Jana Pawła II, Lublin 2018.

Ćwikła L., Leon Halban (1893-1960), [w:] A. Dębiński, W.S. Staszewski, M. Wójcik (red.), Profesorowie prawa Katolickiego Uniwersytetu Lubelskiego, Lublin 2008, s. 159-166.

Dębiński A., W.S. Staszewski, M. Wójcik (red.), Dziekani Wydziału Prawa, Prawa Kanonicznego i Administracji Katolickiego Uniwersytetu Lubelskiego Jana Pawła II, Lublin 2008.

Dębiński A., E. Szczot, L. Fiejdasz, J. Jaśkowski (red.), Informator - Wydział Prawa, Prawa Kanonicznego i Administracji KUL, Lublin 2005.

Dębiński A., M. Ganczar, S. Jóźwiak, A. Kawałko, M. Kruszewska-Gagoś, H. Witczak (red.), Księga Jubileuszowa z okazji 90-lecia Wydziatu Prawa, Prawa Kanonicznego i Administracji Katolickiego Uniwersytetu Lubelskiego Jana Pawła II, Lublin 2008.

Dębiński A., Henryk Insadowski (1888-1946), [w:] A. Dębiński, W.S. Staszewski, M. Wójcik (red.), Profesorowie prawa Katolickiego Uniwersytetu Lubelskiego, Lublin 2008, s. 197-204.

Dubiel S., Teodor Bensch (1903-1958), [w:] A. Dębiński, W.S. Staszewski, M. Wójcik (red.), Profesorowie prawa Katolickiego Uniwersytetu Lubelskiego, Lublin 2008, s. 17-23.

Fiejdasz L., Katedra Prawa Kanonizacyjnego, [w:] A. Dębiński i in. (red.), Księga Jubileuszowa z okazji 90-lecia Wydziału Prawa, Prawa Kanonicznego i Administracji Katolickiego Uniwersytetu Lubelskiego Jana Pawła II, Lublin 2008, s. 523-550.

Greszata M., Katedra Kościelnego Prawa Procesowego, [w:] A. Dębiński i in. (red.), Księga Jubileuszowa z okazji 90-lecia Wydziału Prawa, Prawa Kanonicznego i Administracji Katolickiego Uniwersytetu Lubelskiego Jana Pawła II, Lublin 2008, s. 469-492.

Greszata M., Jerzy Grzywacz (1923-1995), [w:] A. Dębiński, W.S. Staszewski, M. Wójcik (red.), Profesorowie prawa Katolickiego Uniwersytetu Lubelskiego, Lublin 2008, s. 149-157.

Greszata-Telusiewicz M., Katedra Kościelnego Prawa Procesowego, [w:] K. Burczak i in. (red.), 100 lat nauk prawnych na Katolickim Uniwersytecie Lubelskim Jana Pawła II, Lublin 2018, s. 299-324. 
Jóźwiak S., Józef Rybczyk (1912-1983), [w:] A. Dębiński, W.S. Staszewski, M. Wójcik (red.), Profesorowie prawa Katolickiego Uniwersytetu Lubelskiego, Lublin 2008, s. 449-455.

Jóźwiak S., Prawo kanoniczne w strukturach Katolickiego Uniwersytetu Lubelskiego, [w:] A. Dębiński i in. (red.), Ksiegga Jubileuszowa z okazji 90-lecia Wydziatu Prawa, Prawa Kanonicznego i Administracji Katolickiego Uniwersytetu Lubelskiego Jana Pawta II, Lublin 2008, s. 391-392.

Kacprzyk W., Katedra Kościelnego Prawa Publicznego i Konstytucyjnego, [w:] A. Dębiński i in. (red.), Ksiega Jubileuszowa z okazji 90-lecia Wydziału Prawa, Prawa Kanonicznego i Administracji Katolickiego Uniwersytetu Lubelskiego Jana Pawła II, Lublin 2008, s. 493-510.

Kaczor A., Katedra Teologii i Norm Ogólnych Prawa Kanonicznego, [w:] A. Dębiński i in. (red.), Ksiega Jubileuszowa z okazji 90-lecia Wydziału Prawa, Prawa Kanonicznego i Administracji Katolickiego Uniwersytetu Lubelskiego Jana Pawła II, Lublin 2008, s. 577-589.

Kaleta P., Katedra Norm Ogólnych i Kościelnego Prawa Majątkowego, [w:] K. Burczak $\mathrm{i}$ in. (red.), 100 lat nauk prawnych na Katolickim Uniwersytecie Lubelskim Jana Pawta II, Lublin 2018, s. 325-337.

Krukowski J., Józef Gommar Michiels (1890-1965), [w:] A. Dębiński, W.S. Staszewski, M. Wójcik (red.), Profesorowie prawa Katolickiego Uniwersytetu Lubelskiego, Lublin 2008, s. 299-304.

Miziński A.G., Katedra Kościelnego Prawa Karnego, [w:] A. Dębiński i in. (red.), Ksiegga Jubileuszowa z okazji 90-lecia Wydziału Prawa, Prawa Kanonicznego i Administracji Katolickiego Uniwersytetu Lubelskiego Jana Pawła II, Lublin 2008, s. $437-452$.

Ordon M., Józef Pruszkowski (1837-1925), [w:] A. Dębiński, W.S. Staszewski, M. Wójcik (red.), Profesorowie prawa Katolickiego Uniwersytetu Lubelskiego, Lublin 2008, s. 387-391.

Orzeszyna K., Józef Florczak (1887-1943), [w:] A. Dębiński, W.S. Staszewski, M. Wójcik (red.), Profesorowie prawa Katolickiego Uniwersytetu Lubelskiego, Lublin 2008, s. 135-138.

Pruszkowski J. [P.J.K. Podlasiak], Martyrologium czyli męczeństwo Unii na Podlasiu, cz. 1, Kraków 1905.

Pruszkowski J. [P.J.K. Podlasiak], Martyrologium czyli męczeństwo Unii na Podlasiu, cz. 2, Lublin 1917.

Sitarz M., Jan Wiślicki (1879-1944), [w:] A. Dębiński, W.S. Staszewski, M. Wójcik (red.), Profesorowie prawa Katolickiego Uniwersytetu Lubelskiego, Lublin 2008, s. 509-512.

Sitarz M., Katedra Kościelnego Prawa Publicznego i Konstytucyjnego, [w:] K. Burczak $\mathrm{i}$ in. red., 100 lat nauk prawnych na Katolickim Uniwersytecie Lubelskim Jana Pawta II, Lublin 2018, s. 339-359. 
Skorupa A., Jan Roth (1870-1944), [w:] A. Dębiński, W.S. Staszewski, M. Wójcik (red.), Profesorowie prawa Katolickiego Uniwersytetu Lubelskiego, Lublin 2008, s. $443-448$.

Skorupa A., Katedra Prawa Instytutów Życia Konsekrowanego i Stowarzyszeń Życia Apostolskiego, [w:] A. Dębiński i in. (red.), Ksiegga Jubileuszowa z okazji 90-lecia Wydziatu Prawa, Prawa Kanonicznego i Administracji Katolickiego Uniwersytetu Lubelskiego Jana Pawta II, Lublin 2008, s. 511-521.

Stasiak M., Piotr Katwa (1893-1974), [w:] A. Dębiński, W.S. Staszewski, M. Wójcik (red.), Profesorowie prawa Katolickiego Uniwersytetu Lubelskiego, Lublin 2008, s. 217-226.

Syczewski T., Katedra Kościelnego Prawa Matżeńskiego i Rodzinnego, [w:] A. Dębiński i in. (red.), Ksiega Jubileuszowa z okazji 90-lecia Wydziału Prawa, Prawa Kanonicznego i Administracji Katolickiego Uniwersytetu Lubelskiego Jana Pawła II, Lublin 2008, s. 453-467.

Tymosz S., Walenty Wójcik (1914-1990), [w:] A. Dębiński, W.S. Staszewski, M. Wójcik (red.), Profesorowie prawa Katolickiego Uniwersytetu Lubelskiego, Lublin 2008, s. 513-525.

Tymosz S., Piotr Hemperek (1931-1992), [w:] A. Dębiński, W.S. Staszewski, M. Wójcik (red.), Profesorowie prawa Katolickiego Uniwersytetu Lubelskiego, Lublin 2008, s. 167-176.

Tymosz S., Katedra Historii Źródeł Kościelnego Prawa Polskiego, [w:] A. Dębiński i in. (red.), Ksiega Jubileuszowa z okazji 90-lecia Wydziału Prawa, Prawa Kanonicznego i Administracji Katolickiego Uniwersytetu Lubelskiego Jana Pawła II, Lublin 2008, s. 413-435.

Wojciechowski G., Jan Nowicki (1894-1973), [w:] A. Dębiński, W.S. Staszewski, M. Wójcik (red.), Profesorowie prawa Katolickiego Uniwersytetu Lubelskiego, Lublin 2008, s. 309-314.

Wojciechowski G., Edmund Przekop (1937-1999), [w:] A. Dębiński, W.S. Staszewski, M. Wójcik (red.), Profesorowie prawa Katolickiego Uniwersytetu Lubelskiego, Lublin 2008, s. 393-398.

\section{YEARS OF CANON LAW AT THE JOHN PAUL II CATHOLIC UNIVERSITY OF LUBLIN Sum mary}

100 Years of Canon Law at the John Paul II Catholic University of Lublin gives a picture of an invaluable research, didactic and organisational effort. Canon law that organises the life of the community of the Church requires scientific discourse and following the fast rhythm of life. The principle of ius sequitur vitam 
also applies to canon law. The changing requirements of life necessitate introducing new legal regulations. Hence, in those 100 years, two Codes of 1917 and 1983, their canons, became the basis for scientific reflection, which generated scientific commentaries. The professors of the Faculty of Canon Law were actively involved in their preparation. They are authors of countless entries in encyclopaedias and lexicons. Papers delivered at congresses and conferences attest to the professors' active participation in scientific life. They also constitute an important contribution to the promotion of the University. The faculty employees educated priests and lay people from many countries, such as Ukraine, Slovakia, the Czech Republic, Belarus, and Lithuania. The involvement of our professors in the preparation of various church and state legal acts attests to the recognised expertise of the canonists from KUL. Today, when we thank God for the gift of 100 years of the University and the Faculty, we want to express our gratitude for their intellectual efforts. Finding in them the best models to follow, we want to remember their scientific endeavours and, according to our skills, continue to serve Deo et Patriae.

Key words: canon law, university, faculty, institute, department, anniversary

\section{0 ЛЕТ КАНОНИЧЕСКОГО ПРАВА В ЛЮБЛИНСКОМ КАТОЛИЧЕСКОМ УНИВЕРСИТЕТЕ ИОАННА ПАВЛА II}

\section{Резюме}

100 лет канонического права в Люблинском Католическом Университете Иоанна Павла II дают представление о бесценных исследованиях, преподавательских и организационных усилиях. Каноническое право, организующее жизнь церковного сообщества, требует научного дискурса и следования быстрому ритму жизни. Принцип ius sequitur vitam также применим к каноническому праву. Изменение жизненных требований заставляет законодателя нуждаться в правовых нормах. Следовательно, за эти 100 лет два Кодекса 1917 и 1983 годов, их каноны стали основой для научных размышлений, что привело к научным комментариям. Профессора факультета канонического права принимали активное участие в их подготовке. Авторство профессорско-преподавательского состава факультета несметное количество записей в энциклопедиях и лексиконах. Доклады, представленные на конгрессах и конференциях, свидетельствуют об активном участии профессоров в научной жизни. Они также вносят значительный вклад в продвижение университета. Сотрудники факультета обучали священников и мирян из 
многих стран, Украины, Словакии, Чехии, Белоруссии и Литвы. Участие наших профессоров в подготовке различных церковных и государственных правовых актов доказывает признанный авторитет канонистов Люблинского католического университета. Сегодня, когда мы благодарим Бога за дар 100-летия университета и факультета, мы хотим выразить благодарность за их интеллектуальные усилия. Приводя лучшие примеры, мы хотим не забыть об их научных усилиях и, в соответствии с их навыками, продолжать служить Deo et Patriae.

Ключевые слова: каноническое право, университет, факультет, институт, кафедра, юбилей 